\title{
Molecular Basis for the Deficiency of Complement 1 Inhibitor in Type I Hereditary Angioneurotic Edema
}

\author{
Marco Cicardi, Takashi Igarashi, Fred S. Rosen, and Alvin E. Davis III \\ Department of Pediatrics, Harvard Medical School, and the Divisions of Immunology and Nephrology, \\ The Children's Hospital, Boston, Massachusetts 02115
}

\begin{abstract}
Hereditary angioneurotic edema (HANE) results from deficiency of complement 1 inhibitor (C1 INH). In type I HANE, C1 INH is present in serum at levels $5-30 \%$ of normals. Using cultured monocytes and biosynthetic labeling of proteins, $\mathrm{C} 1$ INH was detected in supernatants of cells from HANE patients at levels $20 \%$ of those detected in normals. The intracellular reduction of C1 INH in patients' monocytes approached 50\%. The study of C1 INH messenger RNA (mRNA) by Northern blot analysis indicated that in HANE patients' monocytes a message of normal size is present at about half the concentration of that from normal cells. One of the patients analyzed showed the presence of a genetically inherited abnormal mRNA $(1.9 \mathrm{~kb})$ in addition to the normal mRNA (2.1 kb). Southern blot analysis of DNA from peripheral blood leukocytes did not show any difference in quantity or in sizes of endonuclease restriction fragments between patients and normals. The defect(s), therefore, in type I HANE is pretranslational, but is not due to a deletion or to a major chromosomal rearrangement.
\end{abstract}

\section{Introduction}

Hereditary angioneurotic edema (HANE) ${ }^{1}$ results from the deficiency of complement 1 esterase inhibitor $(\mathrm{Cl} \mathrm{INH})(1,2)$ and is the most common human disease related to a genetic defect of a complement component. The disease is inherited as an autosomal dominant trait and it is clinically characterized by recurrent attacks of angioedema, which can be life threatening when the larynx is involved (3). Two genetic types of HANE have been described: one, comprising $85 \%$ of patients, is characterized by decreased levels of an apparently normal C1 INH protein (Type I); the other by normal or elevated antigenic levels of $\mathrm{Cl}$ INH because of the presence of a dysfunctional mutant protein together with low levels of the normal protein (type II) $(4,5)$. The mutant proteins have been shown to be electrophoretically and functionally heterogeneous $(4,6)$. Functional levels of $\mathrm{Cl}$ INH in serum of type I HANE patients range from 5 to

\footnotetext{
Portions of this work were presented at the XIth International Complement Workshop, November 1985, Miami, FL.

Address reprint requests to Dr. Davis, Children's Hospital, 300 Longwood Ave., Boston, MA 02115.

Received for publication 14 May 1986.

1. Abbreviations used in this paper: $\mathrm{Cl} \mathrm{INH}$, complement 1 esterase inhibitor; HANE, hereditary antioneurotic edema.
}

J. Clin. Invest.

(C) The American Society for Clinical Investigation, Inc. 0021-9738/87/03/0698/05 \$1.00

Volume 79, March 1987, 698-702
$30 \%$ of normal in contrast with the $50 \%$ that would be expected in the heterozygous state. From in vivo turnover studies (7) it has been proposed that at half-normal concentration of $\mathrm{Cl}$ INH there is activation of $\mathrm{Cl}$ and/or other enzyme systems in which this protein acts as an inhibitor. This in turn could lead to consumption of normal $\mathrm{Cl}$ INH that falls below $50 \%$ of normal $(7,8)$.

The hepatocyte is the major site of synthesis of $\mathrm{Cl}$ INH (9); recent evidence has been presented that this protein is also synthesized and secreted by cultured human peripheral blood monocytes (10). In the present study, also using human monocytes in culture, we examined the molecular basis for the defect in synthesis of $\mathrm{Cl}$ INH in type I HANE patients.

\section{Methods}

Media and reagents. Hanks' balanced salt solution, Dulbecco's modified Eagles medium lacking methionine, and fetal bovine serum were purchased from Gibco (Grand Island, NY), and medium 199 from M. A. Bioproducts (Walkersville, MD). $\left.{ }^{35} \mathrm{~S}\right]$ Methionine (specific radioactivity $1,000 \mathrm{Ci} / \mathrm{mmol}$ ), $\left[{ }^{32} \mathrm{P}\right]$ Deoxycytidine triphosphate (specific radioactivity 3,000 Ci/mmol), and $\mathrm{EN}^{3} \mathrm{HANCE}$ solution were obtained from New England Nuclear (Boston, MA). ${ }^{14} \mathrm{C}$-methylated protein standards were from Amersham Corp. (Arlington heights, IL). Sodium dodecyl sulfatepolyacrylamide gel electrophoresis (SDS-PAGE) reagents were purchased from Bio-Rad Laboratories (Rockville Centre, NY), and IgG Sorb from Enzyme Center (Cambridge, MA). Goat antihuman $\mathrm{Cl}$ INH and antihuman $\mathrm{C} 3$ were from Atlantic Antibodies (Westbrook, ME), and restriction endonucleases were from New England Biolabs (Beverly, MA). Nick translation kits were obtained from Bethesda Research Laboratories (Gaithersburg, MD).

Patients. We studied six patients from four kindred with type I HANE. Synthesis studies were performed on patients from three of the four kindred, and in the protein synthesis studies and the Northern blot analysis one representative of each kindred is presented. With the two kindred in which two members were studied, one individual is presented from each kindred, since the results in each member of the same kindred were virtually identical. In the Southern blot analysis, one member of each kindred is presented, although the other members were also studied, with identical results. All patients had taken no medications, including attenuated androgens (11), for at least 1 wk before the time blood was drawn for monocyte cultures.

Monocyte cultures. Monocyte monolayers were established by adherence of dextran purified leukocytes $\left(5-10 \times 10^{6}\right.$ cells $\left./ \mathrm{ml}\right)$ on siliconized glass coverslips as previously described (12). For RNA extraction, cell suspensions were adhered to 100 - $\mathrm{mm}$ siliconized glass petri dishes rather than coverslips.

Biosynthetic labeling. Confluent monolayers grown for different time periods in medium 199 containing 10\% fetal bovine serum were rinsed and incubated for specific time periods in methionine-free Dulbecco's modified Eagles medium containing $\left[{ }^{35} \mathrm{~S}\right]$ methionine $(500 \mu \mathrm{Ci} / \mathrm{ml})$. At the end of the pulse period, the culture medium was harvested and monolayers were lysed as previously described (13), or in pulse-chase experiments was transferred for varying time periods to medium 199 containing unlabeled methionine. At the end of each chase period, media were harvested and the monolayers lysed. Total protein synthesis was 
estimated by trichloroacetic acid (TCA) precipitation of aliquots of cell lysates and culture fluids (14). Incorporation of ${ }^{35} \mathrm{~S}$ into individual immunoprecipitated proteins was determined in gel slices after incubation with $15 \%$ hydrogen peroxide for $16 \mathrm{~h}$ and addition of Scinti Verse I (Fisher Scientific Co., Springfield, NJ). For each patient a normal control was cultured at the same time; the TCA-estimated total protein synthesis did not vary by $>20 \%$ between patient and control.

Immunoprecipitation. Immunoprecipitation from cell lysates and cell supernatants was performed by binding of the immune complex to Staphylococcal protein A after overnight incubation with antibody (13). Samples were then analyzed by SDS-PAGE (7.5\% polyacryalmide) (15). Radioactive ${ }^{14} \mathrm{C}$-labeled standards were included in each gel. After electrophoresis the gel was stained with Coomassie Brilliant Blue, impregnated with EN ${ }^{3} \mathrm{HANCE}$, dried, and exposed to Kodak XAR-5 film at $-70^{\circ} \mathrm{C}$. Autoradiographs were scanned by soft laser densitometry.

RNA isolation and blot analysis. Total cellular RNA was isolated from adherent monocyte monolayers by lysis with guanidinium thiocyanate and centrifugation through cesium chloride density gradients (16). RNA was quantified by absorbance at $260 \mathrm{~nm}$. The yield of total RNA from normal subjects and from patients was the same (5-10 $\mu \mathrm{g} /$ $10^{6}$ cells). Total cellular RNA denatured with formaldehyde and formamide was separated by electrophoresis in formaldehyde-containing agarose gels. Samples were then transferred to nitrocellulose filters and hybridized with a $\mathrm{Cl}$ INH cDNA probe ${ }^{32} \mathrm{P}$-labeled by nick translation (17)

DNA isolation and blot analysis. DNA was prepared from peripheral blood leukocytes as previously described (18). DNA was digested with restriction enzymes and subjected to agarose gel electrophoresis, transferred to nitrocellulose filters, and hybridized with the ${ }^{32} \mathrm{P}$-labeled $\mathrm{Cl}$ INH cDNA probe (19) (Southern blot analysis). Isolation and characterization of the 950-base pair C1 INH complementary DNA (cDNA) clone ( $\mathrm{pCl}$ INH 1) has been described (20). The probe used for both RNA and DNA analysis was the 600-base pair Pst I fragment of pC1 INH 1 isolated as described (20).

\section{Results}

Synthesis and secretion of Cl INH. Pulse experiments were performed with peripheral blood monocytes, and cultured for $1 \mathrm{wk}$ from both normal controls and HANE patients. C1 INH appeared in the cell lysates as a single band with a molecular weight of 80,000 , which probably represents an underglycosylated form of the protein, since it is the same size as purified $\mathrm{Cl}$ INH deglycosylated with trifluoromethanesulfonic acid (21) (Fig. 1). The intracellular $\mathrm{C} 1 \mathrm{INH}$ levels in the three patients were $43 \%$ (patient 1), $53 \%$ (patient 2), and 35\% (patient 3) of normal controls cultured at the same time, as determined by soft laser densitometry of autoradiographs or by quantitation of ${ }^{35} \mathrm{~S}$-incorporation in gel slices. The sample from patient 1 is shown in Fig. 1, lane 2, and a normal's sample is shown in Fig. 1, lane 1. In comparison with that from normal monocytes, intracellular $\mathrm{C} 1 \mathrm{INH}$ from the monocyte lysates from each of the other type I HANE patients appeared virtually identical to the one shown in Fig. 1, lane 2. When the protein secreted into the supernatants was analyzed, the difference between normals and patients increased. An immunoprecipitable protein with a molecular weight of 105,000 , which is identical in size to fully glycosylated C1 INH, is secreted by cultured monocytes from both normal individuals and from patients. However, the quantity of this secreted $\mathrm{Cl}$ INH from patients' monocytes is $24 \%$ (patient 1 ; Fig. 1, lane 7), $18 \%$ (patient 2; Fig. 1, lane 5), and 14\% (patient 3; Fig. 1, lane 4) that of normal individuals, as estimated both by soft laser densitometry and by measurement of specific ${ }^{35} \mathrm{~S}$-incorporation in gel slices. For comparison, the patients' $\mathrm{C} 1 \mathrm{INH}$ levels, de-

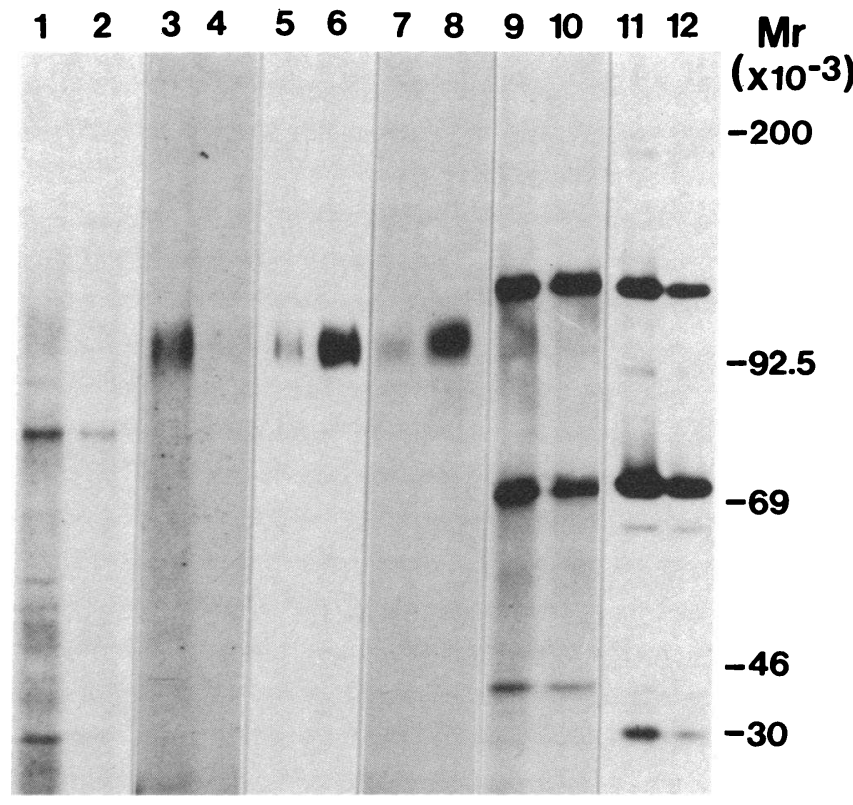

Figure 1. Biosynthesis of C1 INH (lanes 1-8) and C3 (lanes 9-12) by monocytes from normal individuals (lanes $1,3,6,8,10$, and 11 ) and HANE patients (lanes 2, 4, 5, 7, 9, and 12). Cells were in culture for 1 wk or $2 \mathrm{~d}$ (lanes 7 and 8 ). Lanes 1 and 2 represent immunoprecipitates from cell lysates after a 6-h pulse period. Lanes 3-12 represent immunoprecipitates from cell supernatants pulsed for $24 \mathrm{~h}$. The nonspecific bands seen particularly in cell lysates appear inconstantly and are not blocked by purified $\mathrm{Cl}$ INH.

termined immunochemically, were 23,25 , and $29 \%$ of normal for patients 1,2, and 3, respectively.

Both intracellular and extracellular $\mathrm{C} 1 \mathrm{INH}$ bands were proven to be specific by their disappearance when antiserum against $\mathrm{Cl}$ INH was absorbed with excess purified protein. The specificity of the reduction in C1 INH synthesis in HANE patients was assessed by precipitating $\mathrm{C} 3$ from the same samples. Comparable quantities of $\mathrm{C} 3$ were detected in normals and patients (Fig. 1, lanes 9-12). To examine whether C1 INH synthesis and its reduction in HANE patients was also true of monocytes early in culture, cells were pulsed after the first day in culture with the same results as described above (Fig. 1, lanes 7 and 8). To evaluate the rate of secretion of $\mathrm{Cl}$ INH, pulse-chase experiments were performed. With this approach it was possible to show that $\mathrm{Cl}$ INH was rapidly secreted from normal monocytes with $<50 \%$ detectable intracellularly after $90 \mathrm{~min}$ and only trace amounts after $360 \mathrm{~min}$ (Fig. 2). Fully glycosylated C1 INH was readily detectable in the extracellular medium by $90 \mathrm{~min}$ and continued to accumulate at 360 and $1400 \mathrm{~min}$ as it disappeared from the intracellular compartment. Pulse-chase experiments with cultured monocytes from HANE patients confirmed the reductions in both intracellular and secreted $\mathrm{C} 1 \mathrm{INH}$. However, there were no differences apparent in the kinetics of synthesis or secretion compared with normals. Intracellular $\mathrm{Cl}$ INH disappeared and extracellular protein appeared at the same rates as in normal control cultures.

Analysis of CI INH mRNA and DNA. Monocyte RNA and leukocyte DNA were isolated from patients and controls. Equal quantities of RNA from normal individuals and from patients were subjected to Northern blot analysis. The same size messenger RNA (mRNA), 2.1 kilobase (kb), specific for $\mathrm{Cl} \mathrm{INH}$, 


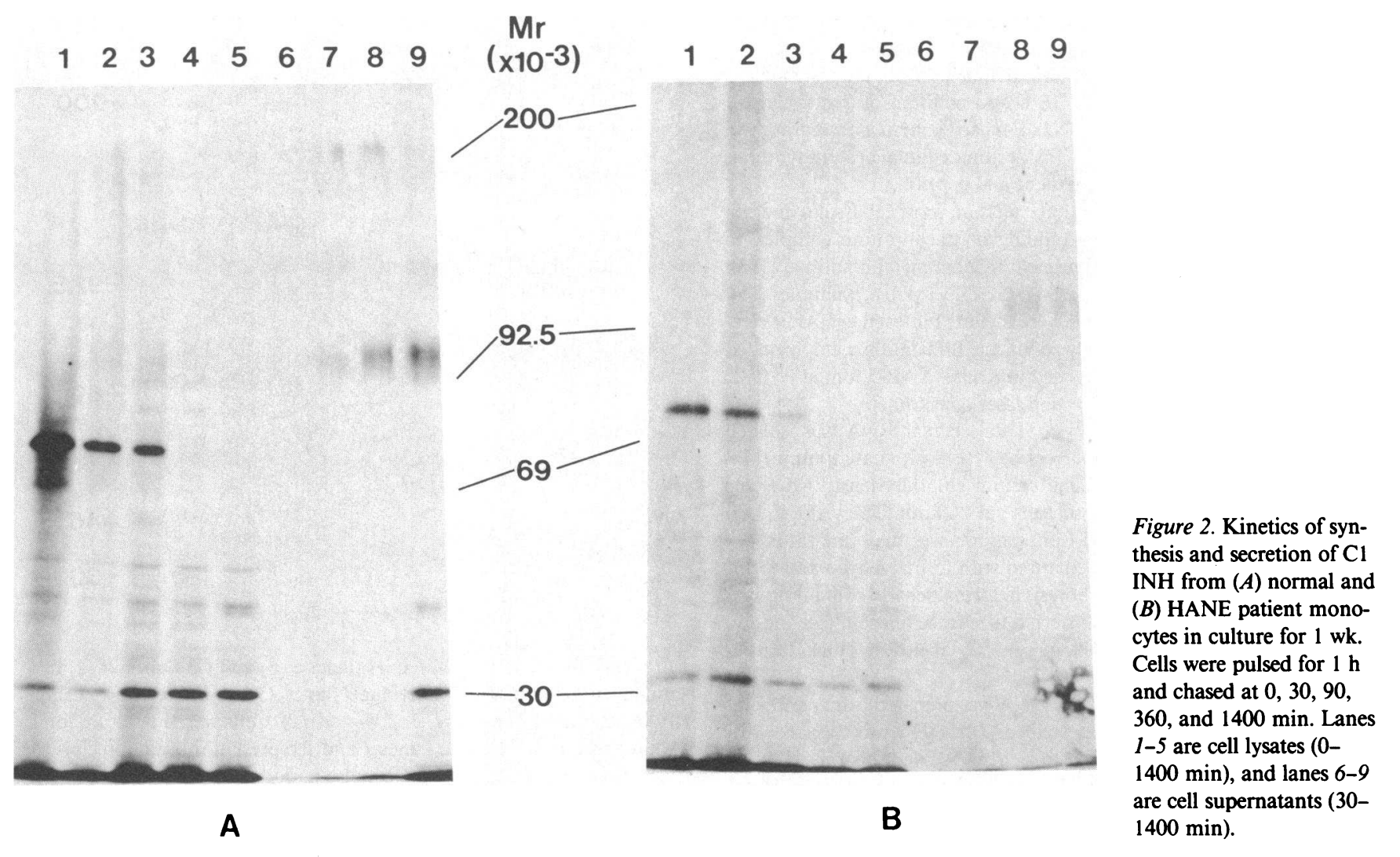

was found in both normals and HANE patients. However, as estimated by soft laser densitometry of the autoradiographs, the patients' $\mathrm{C} 1$ INH mRNA levels were reduced to $40 \%$ (patient 1; Fig. $3 A$, lane 2), $48 \%$ (patient 2; Fig. $3 A$, lane 3 ), and $45 \%$ (patient 3; Fig. $3 A$, lane 4). The same blot, hybridized with a probe for the third component of complement, showed mRNA bands of equal intensity in all the samples (data not shown). In one of the three patients examined (Fig. $3 A$, lane 3 ), a second mRNA band of $1.9 \mathrm{~kb}$, hybridizing with the C1 INH cDNA probe, was detected. This band was of the same intensity as the $2.1-\mathrm{kb}$ band. To avoid the possibility of an artifact and to check whether this abnormality was a genetic characteristic inherited with HANE, different RNA preparations from monocytes from this patient and from two of her siblings were analyzed. The double-band pattern of $\mathrm{Cl}$ INH mRNA was present again in the patient and in her brother, who also has HANE (Fig. $3 \mathrm{C}$ ). The other sibling, who does not have HANE, showed a normal C1 INH mRNA (not shown). Southern blot analysis of the $\mathrm{Cl}$ INH gene did not show any difference in the amount of DNA between normals and patients or in the size of fragments produced by digestion with nine different restriction endonucleases (Fig. 4).

\section{Discussion}

In this study we have provided direct evidence that $\mathrm{Cl}$ INH deficiency in type I HANE patients is due to a reduction in synthesis of the protein, and that this reduction is related to a pretranslational defect. Monocytes from HANE patients were cultured for various lengths of time and showed a reduction in C1 INH in cell lysates that ranged from 35 to $53 \%$ of normal controls. C1 INH mRNA levels were consistent with these findings (see below). However, secreted $\mathrm{Cl}$ INH protein in cell supernatants was reduced to $14-24 \%$ of normal controls. These values are similar to the serum levels of $\mathrm{Cl}$ INH in HANE patients (23-29\% of normal in the patients presented here). In most heterozygous deficiencies of plasma proteins, including other complement components, levels are reduced to $\sim 50 \%$ of normal.

To rule out the possibility that the discrepancy between intracellular and extracellular levels of $\mathrm{Cl}$ INH could be due to a co-existent secretory defect, pulse-chase experiments were performed. These experiments demonstrated that the kinetics of secretion were the same in normal and patient monocytes. In each, $>50 \%$ of the $\mathrm{Cl}$ INH was secreted within $90 \mathrm{~min}$ and only trace amounts of the protein were detected intracellularly after $360 \mathrm{~min}$. There was no accumulation of intracellular $\mathrm{Cl}$ INH in cultured monocytes from patients. It is therefore unlikely that the reduction in extracellular $\mathrm{Cl}$ INH levels compared with intracellular is due to a defect in the kinetics of secretion. The data suggest that $\mathrm{Cl}$ INH in patient monocyte cultures is consumed during or after secretion. The data also are compatible with the previous suggestion $(7,8)$ that protease activation in the presence of half-normal $\mathrm{Cl}$ INH concentrations leads to this consumption of $\mathrm{Cl} \mathrm{INH}$, which then is decreased further to below $50 \%$ of normal. The present study, however, does not define the mechanism by which this happens. Activation of $\mathrm{Cl}$ is probably not the main factor, since the phenomenon is also present when cells are analyzed early in culture. At this time, according to previous data (22), active macromolecular $\mathrm{Cl}$ is not produced by monocytes. However, it is still possible that other proteases, physiologically inhibited by $\mathrm{Cl}$ INH, are acti- 


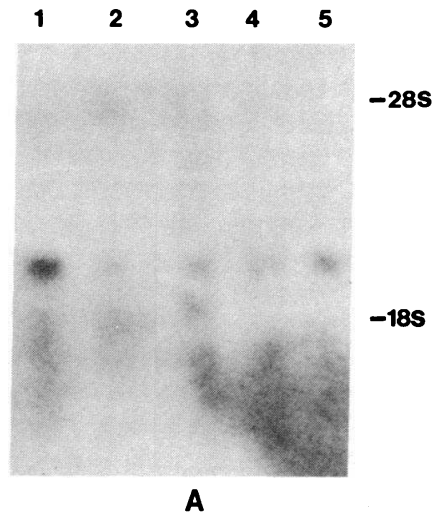

1. $2 \begin{array}{llll} & 3 & 4 & 5\end{array}$

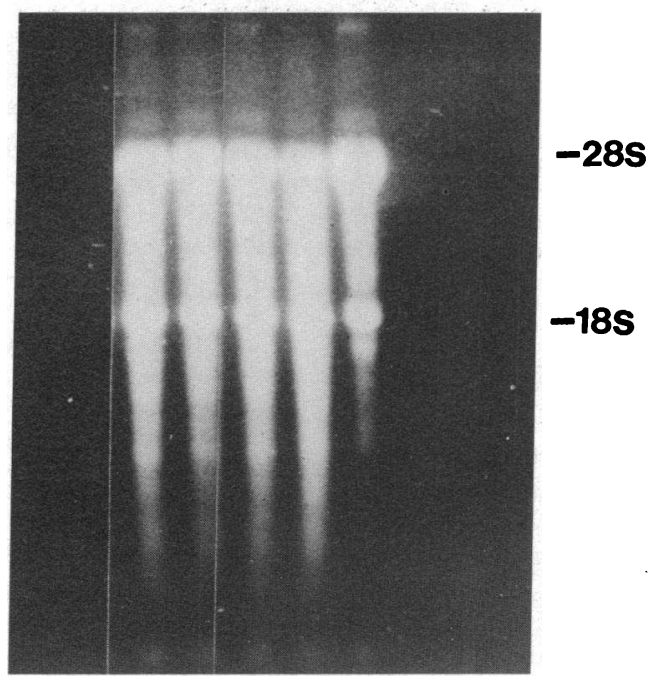

B

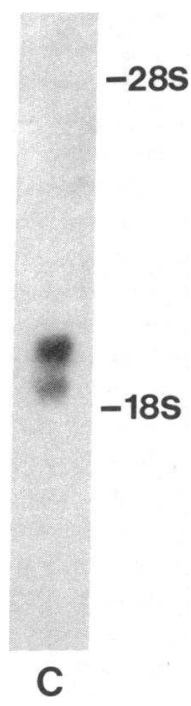

Figure 3. Monocyte RNA from normals (lanes 1 and 5) and HANE patients (lanes 2-4). $A$ is the autoradiograph of the Northern blot; lane 3 shows the patient with two different sizes of C1 INH mRNA. $B$ is the ethidium bromide-stained gel from which the Northern blot was generated, showing that comparable amounts of total RNA were loaded in each lane. $C$ is the autoradiograph of the Northern blot from the sibling with HANE of the patient shown in $A$, lane $3.18 \mathrm{~S}$ and $28 \mathrm{~S}$ indicate the positions of $18 \mathrm{~S}$ and $28 \mathrm{~S}$ ribosomal RNA.

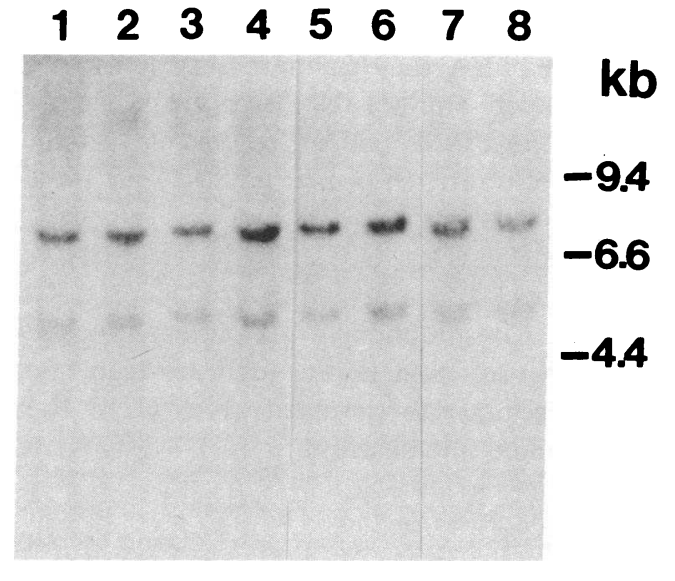

Figure 4. Southern blot analysis of leukocyte DNA from normals (lanes 1-4) and HANE patients (lanes 5-8). DNA was digested with Bam $\mathrm{H} 1$ and hybridized with the $\mathrm{C} 1$ INH CDNA probe.

vated in cell supernatants deficient in this protein, resulting in its further reduction.

In previous studies of $\mathrm{Cl}$ INH synthesis from normal human monocytes its production was detected after a minimum of 1 wk in culture (10) when the cells became macrophage-like (12), or after stimulation with lymphokines (22). Our data indicate that $\mathrm{C} 1 \mathrm{INH}$ is synthesized from the 1st day in culture (2nd day after drawing blood from the donor). C1 INH mRNA was also detected in freshly isolated mononuclear cells prepared by centrifugation through Ficoll-Hypaque (unpublished observation). This suggests that the production of this protein is a physiologic property of circulating monocytes. This synthesis from monocytes early in culture is also characteristic of alpha-1-antitrypsin, but is not common for complement components (23). C1 INH, as well as alpha-1-antitrypsin, has been demonstrated to belong to the serpin "super family" of protease inhibitors (20). These data may suggest a physiologic role for circulating monocytes in local regulation and prevention of inflammatory phenomena.

The recent isolation of a C1 INH cDNA clone (20) allowed us to investigate the molecular basis for $\mathrm{Cl}$ INH deficiency in HANE. Total cellular RNA was extracted from normal human monocytes in culture and, after Northern blot analysis, a $\mathrm{Cl}$ INH mRNA of $2.1 \mathrm{~kb}$ was detected. This size is consistent with that found for RNA isolated from the human hepatoma-derived cell line HepG2 (20), and with the molecular weight of deglycosylated $\mathrm{C} 1 \mathrm{INH}$. In agreement with the amount of $\mathrm{C} 1 \mathrm{INH}$ protein in the intracellular compartment, $\mathrm{Cl}$ INH mRNA in HANE patients was found to be present at about half the level of normal controls, indicating the existence of a pretranslational defect. An analogous defect has been found in humans in the case of the deficiency of the second component of complement (24), while gene deletion is responsible for deficiency of C4 and 21 -hydroxylase $(25,26)$. The possibility of a major deletion or rearrangement in the $\mathrm{C} 1 \mathrm{INH}$ gene was excluded by the absence of gross differences when genomic DNA from normals and HANE patients was studied by restriction endonuclease digestion and Southern blot analysis.

In two related patients with type I HANE a C1 INH mRNA that was $0.2 \mathrm{~kb}$ smaller than the normal mRNA was detected. This band co-existed with the normal message and each made up 50\% of the amount of C1 INH mRNA in normals. The 
data suggest that this characteristic is genetically determined and is related to the presence of HANE. No abnormal protein could be immunoprecipitated with anti-C1 INH from the cell supernatants or the cell lysates of this patient, suggesting that the abnormal message is not translated or that it is translated into a protein that is rapidly destroyed in the cytoplasm. In conclusion, we suggest that the deficiency of $\mathrm{C} 1 \mathrm{INH}$ in type I HANE is due to a pretranslational defect leading to a reduction in $\mathrm{Cl}$ INH synthesis of $50 \%$. Consumption of the protein probably takes place during or after secretion, leading to further reduction. This consumption determines the levels at which $\mathrm{Cl}$ INH is detected in cell supernatants and in serum from HANE patients.

\section{Acknowledgments}

We thank Dr. Harvey Colten for many helpful discussions during the course of these studies.

This work was supported by U. S. Public Health Service grants AM 34604, AI 21163, HD 17461, and RR 02172, and by the March of Dimes Birth Defects Foundation grant 1-775. Dr. Cicardi received fellowship support from CNR (Rome) Special Project Basi Molecolari delle Malattie Genetiche. This work was done during the tenure of an established investigatorship of the American Heart Association (Dr. Davis) and with funds contributed in part by the American Heart Association Massachusetts Affiliate, Inc.

\section{References}

1. Donaldson, V. H., and R. R. Evans. 1963. A biochemical abnormality in hereditary angioneurotic edema. Am. J. Med. Sci. 35:37-44.

2. Landerman, N. S., M. E. Webster, E. L. Becker, and H. E. Ratcliffe. 1962. Hereditary angioneurotic edema. II. Deficiency of inhibitor of serum globulin permeability factor and/or plasma kallikrein. J. Allergy. 33:330-341.

3. Cicardi, M., L. Bergamaschini, B. Marasini, G. Boccassini, A. Tucci, and A. Agostoni. 1982. Hereditary angioedema: an appraisal of 104 cases. Am. J. Med. Sci. 284:2-9.

4. Rosen, F. S., C. A. Alper, J. Pensky, M. R. Klemperer, and V. H. Donaldson. 1971. Genetically determined heterogeneity of the $\mathrm{Cl}$ esterase inhibitor in patients with hereditary antioneurotic edema. J. Clin. Invest. 50:2143-2149.

5. Gadek, J. E., S. W. Hosea, J. A. Gelfand, and M. M. Frank. 1979. Response of variant hereditary angioedema phenotypes to danazol therapy. J. Clin. Invest. 64:280-286.

6. Donaldson, V. H., R. A. Harrison, F. S. Rosen, D. H. Bing, G. Kindness, J. Canar, C. J. Wagner, and S. Awad. 1985. Variability of purified dysfunctional $\mathrm{C} 1$-inhibitor proteins from patients with hereditary angioneurotic edema. J. Clin. Invest. 75:124-132.

7. Quastel, M., R. A. Harrison, M. Cicardi, C. A. Alper, and F. S. Rosen. 1983. Behavior in vivo of normal and dysfunctional $\mathrm{Cl}$ inhibitor in normal subjects and in patients with hereditary angioneurotic edema. J. Clin. Invest. 71:1041-1046.

8. Lachmann, P. J., and F. S. Rosen. 1984. The catabolism of C1 inhibitor and the pathogenesis of hereditary angioedema. Acta Pathol. Microbiol. Immunol. Scand. Sect. C. Suppl. 92:284:35-39.

9. Johnson, A. M., C. A. Alper, F. S. Rosen, and J. M. Craig. 1971.
$\mathrm{Cl}$ inhibitor: evidence for decreased hepatic synthesis in hereditary angioneurotic edema. Science (Wash. DC). 173:553-554.

10. Yeung-Laiwah, A. C., L. Jones, A. O. Hamilton, and K. Whaley. 1985. Complement subcomponent $\mathrm{Cl}$ inhibitor synthesis by human monocytes. Biochem. J. 226:199-205.

11. Gelfand, J. A., R. J. Sherins, D. W. Alling, and M. M. Frank. 1976. Treatment of hereditary angioedema with danazol. Reversal of clinical and biochemical abnormalities. New Engl. J. Med. 295:14441448.

12. Einstein, L. P., E. E. Schneeberger, and H. R. Colten. 1976. Synthesis of the second component of complement by long-term primary culture of human monocytes. J. Exp. Med. 143:114-126.

13. Morris, K. M., D. P. Aden, B. B. Knowles, and H. R. Colten. 1982. Complement biosynthesis by human hepatoma derived cell line HepG2. J. Clin. Invest. 70:906-913.

14. Roberts, B. E., and B. M. Paterson. 1973. Effect of translation of tobacco mosaic virus RNA and rabbit globin 9S RNA in a cell free system from commercial wheat germ. Proc. Natl. Acad. Sci. USA. 70: 2330-2334.

15. Laemmli, U. K. 1970. Cleavage of structural proteins during the assembly of the head of bacteriophage T4. Nature (Lond.). 227:680-686.

16. Chirgwin, J. M., A. E. Przybla, R. J. MacDonald, and W. J. Rutter. 1979. Isolation of biologically active ribonucleic acid from sources enriched in ribonuclease. Biochemistry. 18:5294-5299.

17. Thomas, P. S. 1980 . Hybridization of denatured RNA and small DNA fragments transferred to nitrocellulose. Proc. Natl. Acad. Sci. USA. 77:5201-5205.

18. Whitehead, A. S., D. E. Woods, E. Fleishnick, J. E. Chin, E. J. Yunis, A. J. Katz, P. S. Gerald, C. A. Alper, and H. R. Colten. 1984. DNA polymorphism of the $\mathrm{C} 4$ genes: a new marker for analysis of the major histocompatibility complex. N. Engl. J. Med. 310:88-91.

19. Southern, E. M. 1975. Detection of specific sequences among DNA fragments separated by gel electrophoresis. J. Mol. Biol. 98:503517.

20. Davis, A. E., A. S. Whitehead, R. A. Harrison, A. Dauphinais, G. A. P. Bruns, M. Cicardi, and F. S. Rosen. 1986. Human C1 inhibitor: characterization of cDNA clones and localization of the gene to chromosome 11. Proc. Natl. Acad. Sci. USA. 83:3161-3165.

21. Harrison, R. A. 1983. Human C1 inhibitor: improved isolation and preliminary structural characterization. Biochemistry. 22:5001-5007.

22. Bensa, J. C., A. Reboul, and M. G. Colomb. 1983. Biosynthesis in vitro of complement subcomponent $\mathrm{Clq}, \mathrm{Cls}$, and $\mathrm{Cl}$ inhibitor by resting and stimulated human monocytes. Biochem. J. 216:385-392.

23. Perlmutter, D. H., F. S. Cole, P. Kilbridge, T. H. Rossing, and H. R. Colten. 1985. Expression of the $\alpha_{1}$-proteinase inhibitor gene in human monocytes and macrophages. Proc. Natl. Acad. Sci. USA. 82: 795-799.

24. Cole, F. S., A. S. Whitehead, H. S. Auerbach, T. Lint, H. J. Zeitz, P. Kilbridge, and H. R. Colten. 1985. The molecular basis for genetic deficiency of the second component of human complement. N. Engl. J. Med. 313:11-16.

25. Carroll, M. C., A. Palsdottir, K. T. Belt, and R. R. Porter. 1985. Deletion of complement $\mathrm{C} 4$ and steroid 21-hydroxylase genes in the HLA class III region. EMBO (Eur. Mol. Biol. Organ.) J. 4:2547-2552.

26. White, P. C., M. I. New, and B. Dupont. 1984. HLA-linked congenital adrenal hyperplasia results from a defective gene encoding a cytochrome P-450 specific for steroid 21-hydroxylation. Proc. Natl. Acad. Sci. USA. 81:7505-7509. 